\title{
Three three-letter words in three recent novels in three different languages: God, sex and joy
}

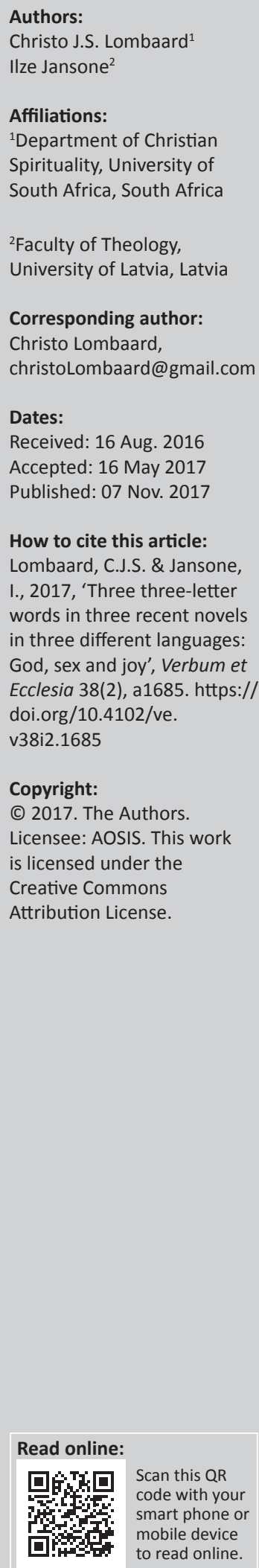

In this article, the authors propose to analyse the ways in which religion and sexuality are related to one another in three recent novels: (1) Fransi Phillips's Die donker god (2007), (2) Inga Žolude's Santa Biblia (2013) and (3) Michel Houellebecq's Soumission [English translation: Submission] (2015). In each case, the novels are briefly placed within their respective literary cultures (Afrikaans, Latvian and French) in order to offer a contextually sensitive analysis. After each of the novels has been discussed related to the three related topoi of God, sex and joy, some comparative remarks are offered in conclusion.

Intradisciplinary and/or interdisciplinary implications: In this contribution, from the theological field of Spirituality Studies, the field of Comparative Literature is approached, seeking to identify aspects of Religiosity and Sexuality from the perspective of Post-Secularity.

\section{Introduction}

\section{$3 \times 3$-letter words}

Although the form of literary analysis followed below fits broadly into the general mode of scholarship when studying literature in a comparative manner (as done in e.g. Lombaard 2009a:334-347; cf. more generally e.g. Eaves 2003; Hamilton 1989; Hart \& Khovacs 2007), the three keywords employed to do so, also as they relate to one another in this contribution, should for the sake of clarity be described. The three terms are, as the title of this paper suggests, 'God', 'sex' and 'joy'.

Firstly, God. ${ }^{1}$ Though the intended referentiality to the divine is often quite clearly, if only implicitly, conceptually delineated within religious groupings, it is quite clear from an academic standpoint that what the term 'God' refers to in different eras and areas (or temporalities and geographies) differs quite markedly (cf. influentially Taylor 2007). Moreover, in a different configuration, the manner in which the divine is referred to within Theological Sciences and within Social Sciences differs too (Lombaard 2014):

Talk of God, the domain of Theology ... has been acknowledged in refined theological reflection as being a function of the category of revelation ... as divine self-disclosure to humanity, without which all talk of God would, for religiously inclined people, become speculative. This insight is, to be sure, itself a confession of faith, namely of the kind that constitutes a tipping point between Theology and the approach of the Humanities or Social Sciences ... Within the Humanities, 'God talk' ... does not require a sense, a confession or a spiritual orientation on the existence of God (and all the implications that that would imply) or not - although the implicit inclination is towards the latter. The Humanities do not consider God. Religious humanity, the psychological and social effects of religiosity and the philosophical implications around ideas about divinity however all do lie within the ambit of such non-theological intellectual consideration and social-scientific investigation. (p. 206)

What is offered here, in this contribution, lies closer to the latter: the ways in which the divine is referred to and the ways in which the divine is related to other topics of analysis are taken into review. This is not to say, however, that within the literary worlds of the texts studied, in the life worlds of the authors of the novels concerned here, or on the part of us as analysts here confessional stances are essentialistically evaluated as either aloof/cold or committed/warm. This is fully in keeping with the post-secular (cf., e.g. Habermas 2008:17-28; Nynäs, Lassander \& Utriainen 2012) atmosphere in which the work is undertaken here. In this currently unfolding broadly cultural ambience related to religiosity, it is namely in a more balanced way than in previous eras both socially and personally in order to be of any inclination towards faith (including none). The wide spectrum of shades of faith, from the most negative to the most positive, and on a different axis, 
from the most involved to the most indifferent, are all in principle (in practice, with rather greater difficulty) accorded equal validity across various human endeavours (cf., e.g., Bailey 1997; Boyce-Tillman 2015; Cupitt 1988; Flanagan \& Jupp 2007; Hay \& Nye 2006; Hochheimer \& Schmidt 2013; Kearney 2010; Kourie 2009:148-173; O'Sullivan \& Flanagan 2012; Schneiders 2003:163-185; Vanhoutte 2015) politically and privately (cf., e.g., Benson 2012 on inclusive liberalism), in a manner neither enforced by violence nor relativised by diversity. Thus, Lombaard (2015c) states:

Whereas in pre-modern society God was everywhere and in modern/post-modern society God was (almost) nowhere, both seem at the same time to be sound within a post-secular society. On personal, experiential scale, the expression 'turn to spirituality' characterises ... increased interest in new or ancient or alternative religions and, within established Christianity, in the quest for more experiential and mystic dimensions to faith. On a broader scale, communities are making sense of different incarnations of the Divine with which they are faced; incarnations, not in the Hindu or Christian senses, but meant here as real life encounters, rather than philosophical abstractions about God in debates on history, ethics, theology, et cetera. God is everywhere: in the new neighbours and the old church buildings, in Hot 100 rock hits as much as in classical choral music, in fashionable jewelry designs and in cool blasphemies, in war and art, in wedding venues and baptism practices and funeral ceremonies, in badly produced televangelism shows one cannot help coming across when scanning through television channels and in ever more popular pilgrimage travels, and so forth. This 'everywhereness' of the religious is not experienced as divine omnipresence; though its sources lie far and wide, it is encountered locally and most often unreflectively. Still - the age old problem of finding God, solved in various Christian traditions by theological emphases on respectively the church, or liturgy, or the sacraments, or the Scriptures, or the Holy Spirit, or liberation, or nature - the Divine remains concealed, and even if perhaps found concretely through experience or conversion or revelation or reason, remains ineffable. In a kind of duality, God is at once $t /$ here and not $t /$ here - a sensibility which is not to be reduced to ontological and epistemological debates of previous eras, but which builds forth on those unanswered awarenesses to now at least feel 'something of', or possibly feel 'at one with' something, Something, or nothing. (pp. 87-88)

It is within this framework that the divine, God, is considered in this contribution.

The second, sex, ${ }^{2}$ is here considered in broader, more existential terms than found in medical manuals or comforting teen guides. With 'sensuality' perhaps a more encompassing word, the reference here is as much to the often culturally implied norm of two loving and committed partners in tender embrace as to what that generally accepted norm would cast as 'alternative', or even 'deviant'. Without expressed or implied preference or degradation, and without regarding matters sexual as inherently problematic (Lombaard 2009b:103-123), the erotic engagement in bodily pleasures (cf. the essays collected in Russel 2003, especially Pinkerton et al. 2003:341-353) in its various forms are implied under the code word 'sex' here. Indeed, the manner of sexual engagement encountered in these novels is not limited to the parameters of the romantic or the occasional; rather, the unusual and the unexpected are the norm here. Although the intended readership may well find itself surprised, even perturbed by some aspects of the sexual encountered in these novels, the sense is less one of upsetting the apple cart than of stretching the readers' imagined reality (and perhaps that of society too) by a measure of literary representation.

Also, we speak here about sexuality, which manifests itself only through the body, namely through the sexual act; thus, it is led by an instinctive, even bestial desire. As such, this sexual desire inclines to form the language of sexuality that lifts:

us into the night where God is absent, where all our actions are addressed to this absence in a profanation which at once identifies it, dissipates it, exhausts itself in it, and restores it to the empty purity of its transgression. (Foucault 1977:31)

While being bestial, such a desire is not sovereign, nor reproductive. Rather, it is a provocative answer to the ethical borders and 'dogmas' of chastity, a necessity for freedom, expressed in a strange protest against various forms of religion (as we can see in Žolude's novel). Such desire leads nowhere; it shows only the animal part in humans, and from such point of view, also 'alternative' or 'deviant' sex can lose its mysticism and become destructive.

Not to be surprised by joy ${ }^{3}$ being not in the last place, this positive human sensation or awareness remains in this contribution free from firm circumscription. Neither the deep and lasting intellectual pleasures of, for instance, academic scholarship nor the most superficial or fleeting sense of excitement at what may be called 'fun' are omitted. As Sen (1985:169-221) has argued in a different field (namely 'capability theory' in social development economics), the validity of the possibility of, here, joy, too, cannot be prescribed, namely determined by outward sources. This is argued for diversely from classics such as Bertrand Russell's contemplative The Conquest of Happiness (1930), indebted to the Old Testament book of some 2300 years earlier, Ecclesiastes (with its recurring slogans on the destruction of death and the enjoyment of life ${ }^{4}$ ), to Csíkszentmihályi's almost 'extreme living'-like Flow concept (1990). Joy is described as such where it is experienced as such.

\section{If the CS Lewis (1955) pun may be pardoned.}

4.Cf. Lombaard (2009c): 'God is far; life is tough; death is everywhere ... The intense irony of this 'theology' is that the finality of death drives one positively to seize the finality of life... In Ecclesiastes 2:24-25, 3:12-13, 5:17, 8:15 and 9:7 ... a divine(given) hedonism becomes the ultimate, albeit temporary, expression of life in the face of death. Small wonder that 20th century French existentialists seem to paralle this ethos (Lohfink 2003:14; Scheffler 1996:16-22): Acceptance of the inevitability of death brings forth a paradoxical rebellion - a revelling in the (limited) good life has to offer ... This exact point has found an interesting turn in a recent philosophy book in South Africa (Goosen 2007), which - as an unintended latter-day analogous work to that of Qohelet - rejects modernist and postmodernist nihilism in favour of sheer hat on Q sheer happiness... Life, for Goosen (2007:43), is both, and not either, its 'radikale afgrondelikheid (radical precipitousness) and its 'oneindige eksessiwiteit' (unending abundance). Taking pleasure in the latter moderates the stark finality of the former Each joyful meal is a sacrament for life, against death. Every delight in food, drin and companionship is an instantaneous eternity ... there is life before death: an existential question of at least equal importance to its more popular corollary, on life after death. There is too little of life and too much in it, for us not to have our fill of it' (Lombaard 2009c:3). 
In this latter respect, already its overlap with the other two key concepts of this contribution, sex and God, can be sensed.

On a methodological note, the choice of the three novels in which the topoi of God-sex-joy are analysed below, may seem to be entirely random. To some extent, the way in which these three texts have been brought together, is unplanned; this, though, not in an indiscriminatingly haphazard way. The paper on which this article is based, was written by the present authors for the 'Post-Secular Stories: the Divine in Contemporary World Literature' conference, held at the LCC International University in Klaipeda, Lithuania, in February 2016. The purpose of this conference was to identity in many forms of modern texts, ranging from management handbooks to medical manuals to films and, as is the case here, novels, unusual or unexpected religious references. With this as the guiding impetus, and having recently read Fransi Phillips's novel Die donker god (2007), the first author here had during 2015 been in discussion with the second author, who knew well and pointed out some parallels to Inga Žolude's 2013 novel Santa Biblia. It was during this time that reviews of Michel Houellebecq's recently published Soumission found their way into the international press (Houellebecq 2015a \& Houellebecq 2015b), drawing the attention of both authors here, though for different reasons: Lombaard, with his academic interest in modern faith developments, and Jansone, with her research interest in French literature, springing from her earlier dissertation. Again, the surprising overlap in some thematic respects presented themselves now relating to Soumission too, and the idea for a joint contribution to the Klaipeda conference crystallised. Two things were clear from the beginning: that the three novels were culturally so diverse, and with no possibility of intertextual influence, that a grand emerging trend could not be spoken of in any way; yet we noted the shared, though not synonymous, and surprising thematic overlay of religion and bodiliness and happiness. Aspects of faith, sensuality and pleasure simply spoke from these pages, though in no preachy or predictable manners. At least an unusual element had been observed, we realised even if by chance, an occurrence not unknown in any form of scholarship. At best, if this insight was put forward, it may coalesce with what others notice in other bodies of literature, with possible insights which may then dawn from that, though that was certainly not uppermost in our minds. Either way, we had happened upon a strategy of interpretation that would lead us deeper into the three literary texts we analysed, to understand some aspects of the internal dynamics in each.

The process of joint authorship, and that at some distance, naturally shows up in our resulting text. The stylistic differences and respective interpretative habits of Lombaard and Jansone can be seen especially in the sections on Die donker god and Santa Biblia, with neither of us being able to read the other's first language. In the rest of this contribution, the signs of initial authorship, detailed dialogue and subsequent editing, at times extending to re-editing, may be detected variously. Though this may perhaps be experienced as rendering some inconsistencies, the value of working together to put forward insight that would not have occurred in any other way outweighs for us the unevenesses in this text, for which we beg our readers' grace.

\section{Phillips's Die donker god}

A respected author of Afrikaans novels and of art criticism, in 'The dark god' Phillips presents a relationship novel in which the association between a student of literature, Pippa, and her somewhat stalker-ish, and older, businessman and $\mathrm{PhD}$ in physics beau called Alex progresses from falling outside of her parents' expectations (cf. Phillips 2007:51-52), to the sexually unusual, to the abusive. (For a fuller summary of the story and an analysis of its symbolic aspects, see Renders 2009:70-82.) The physical aspects are combined in an unpredictable way with religious thematics, namely already with the reference in the title to 'The dark god' - which in the highly religious and highly race-conscious Afrikaans community would immediately raise questions. The fact that the title of the book is printed both on the cover of the book and on the title page in full capitals, makes for no quick answers to any implicit questions Afrikaans readers may have on the metaphorical or religious nature of the referentiality here to the divine.

\section{Text in context}

Popular religious booklets in Afrikaans remain one of the most profitable segments of the South African book market. Erotic literature, on the other hand, draws more controversy than cheques, with only since the literary movement known as Die Sestigers - a renewal movement, the members of which began publishing in the 1960s - this aspect of human life being given serious attention in novels. The initially highbrow literature relatively recently broadened to wider readerships, with publications such as Kleinboer's prizewinning Kontrei (2003), with its doubly illegal subject matter of sex 'across the colour bar' in apartheid South Africa and with prostitutes, the suburban housewife Annelise's Maanvrug (2007), ${ }^{5}$ which was a newspaper sensation for its representation of a different kind of sexual morality set among middle-class Afrikaans women, and the highly respected author Hennie Aucamp's gay eroticism essays in Lendetaal (2011). The impact of the broadly influential Afrikaans literary website Litnet (http://www.litnet.co.za) must also be mentioned, with its section for erotic contributions, LêNet $^{6}$ (http://www.litnet.co.za/category/ onderlangs/hygliteratuur). Although Phillips is comparatively speaking not daringly explicit in her depictions of sex in Die donker god, opting mostly for suggestiveness, the combination with a religious dimension is thematically provocative.

Moreover, this novel is an informed reader's text: it calls deliberately in thematically important ways on other literature. The central text (among various others, from e.g.

5.Interestingly, these two novels set a trend for pseudonymous sexual confessionals, in some ways parallel to the stage-named musicians in the early anti-establishment Afrikaans rock music scene of the 1980 s.

6.The innovative Afrikaans wordplay in all these and similar publications ought not to pass by unnoticed. 
classic Greek, French and Arabic literature) to which reference is made, namely as the favourite story of the main character, Pippa, is the Maeterlinck play (and, later, Debussy opera) Pelléas et Mélisande (1892) - a symbolic piece on the effects, positive and negative, of the erotic. In an intertextual play with especially this source (cf. Renders 2009:77-78), moments within the storyline and some of the characters (Pippa's pet monkey, a gift from Alex, is called Mélisande) unfurl; this, from the very first page of the novel already. However, this intertextual play as plot technique does not take precedence in the analysis below, in order below to keep to the analytic $3 \times 3$ words.

\section{God, sex and joy}

'Die god het die eerste keer verskyn ...' ['The god appeared the first time ...'] - the opening words of the novel (Phillips 2007:7) already allude to some revelatory moment, in which in for instance the Christian or Hindu tradition a divine angel or an avatar from on high makes its appearance - though now, spelt 'god', the indication is (different from on the cover and the title page of the book) clearly metaphorical. Though the reference is to a Western romantic icon - a blonde, intelligent, sensitive young man - the mystical element is maintained by means of a 'knowing - not knowing/unknowing' existential element (cf. also Phillips 2007:28: 'the secret god'; Phillips 2007:91). Though this man is a god, he is however not the god who will play the main role in the novel, and becomes a kind of hero or saviour towards the end of the story. Rather, the dominant male character is a figure that might be better described as a (gnostic) demiurge. Namely, it is on the very next page that the 'dark god' presents himself in Pippa's life, for the first time to her consciousness, though - learnt later - after a time of silent observation (like the Greek mythological Zeus with his many earthly lovers); often during the narrative, this god appears unexpectedly, silently, unannounced. Pippa accepts this god into her being, namely as a virgin into her body, some pages after the initial meeting (Phillips 2007:12), and in the context of observing the cosmic order. His name she only learns some paragraphs later: Alex. He is a being of method and system: he studies the stars, arranges her life, supplies everything; he regards himself as God (Phillips 2007:54 and 72), though conceited (Phillips 2007:128) and, his psychological driving factor, in fear of death (Phillips 2007:163-164). Isolated, her companion becomes only silence (Phillips 2007:41, 78 - even later, along with her child: Phillips 2007:177); he feels empty in the centre of his existence (Phillips 2007:78, 81, 95) - a feeling she, after all, echoes (Phillips 2007:111, 119). While his reason for existence is outer space, hers is inner space (Phillips 2007:139); the 'worlds' that meet are understanding and ruling versus feeling and experience.

God Alex assumes all power - financially and socially, providing care and comfort, food and clothing and entertainment (Phillips 2007:16, 104-108) - while she accepts that, at first willingly, and at the cost of social isolation, but much later and after having been made aware of it by her friends and his family (e.g. Phillips 2007:133, cf. Phillips 2007:153-154), less so, only rebelling against it at the end in dramatic escape and death scenes. Still, for the greater part of the unfolding story, it is in obedience and submission and pain (echoed also in music by Maria Callas - Phillips 2007:41) that she finds sexual joy and a sense of satisfaction in belonging (e.g. Phillips 2007:129, 178, 180). This, while the god who is jealous (Phillips 2007:13, 17, 19, 28, 123-124) assumes all unto himself. This jealousy expresses itself in slight (Phillips 2007:19) and serious (Phillips 2007:109, 170171) acts of physical violence, along with the constant emotional torment. Some of this finds expression in acts of sexual Bondage and Discipline, at times desired on the part of Pippa (Phillips 2007:22, 40, 69, 81, 95-96, 104, 128, 170-171, $178,180)$. The border between wanted sadistic lust and unwanted violence remains vague, even disturbingly permeable.

Taking full control of Pippa's life and being, the god Alex reveals all to her that she has as yet not known or experienced: love, sex, the ordered universe, and when she falls pregnant, motherhood. For this he requires in turn exclusivity and obedience (e.g. Phillips 2007:48, 131), to the point that Pippa loses her freedom and experiences existential fear (e.g. Phillips 2007:100, 179). ${ }^{7}$ During her pregnancy, rather than reading books about babies, she reads a biography of the father of sadism, the Marquis de Sade (Phillips 2007:131-132); her god, Alex, reads The Death of Sardanapolus (it is unclear which of the books by this title; more famous are the similarly titled Delacroix painting and the Berlioz cantata), about an Assyrian king who has his wives, slaves and animals put to death with him - a prefiguration to the violent end of this novel? Still, Pippa finds a kind of fulfilment in this, in a way many would regard as perverted aesthetics: 'Perhaps life looks more beautiful when it is under threat', Pippa says (Phillips 2007:132, translated). On this follows a short theological discussion, on matters such as ensoulment, unity, panentheism and universalism. It seems that God-issues in a way put themselves onto the agenda when end-of-life issues come to the fore. Pippa's sense of religiosity is more in favour of 'a time outside time' and 'an eternity outside time' (Phillips 2007:136 and 138 respectively, translated) than traditional religious traditions.

Planning and taking a trip to Zanzibar cements the novel's symbolism. With connotations of heavenly idyll, Zanzibar is also an island of isolation, with a tragic history of slave trade (Phillips 2007:149-151). Here we find '[t]he unfathomable love relationship that exists between cruelty and beauty' (Phillips 2007:130, translated) - the theme of the novel, in the words of Pippa, as she summarises her impressions of Zanzibar. As tellingly, their wedding is an unattended affair in the Valley of Desolation.

Religious language, sexual experiences and searching for joy in both inner and outer beauty all thus mix in unusual ways in this novel, in an intricate manner which reflects quite

7.Some parallels run here with the Hebrew Bible book of Hosea, in which Yahweh and the people of Israel have a somewhat similar relationship. These parallels, however seem unintended on the part of Phillips. 
realistically the relative chaos as life unfolds for most people, relating to these and other themes.

\section{Žolude's Santa Biblia}

The narrative of Santa Biblia is about three people - Nima, Toor and Lev - wandering through 12 stations. Each station has a symbolic title (Soledad, Circumcision, Virgin, Fuego, Vierge Noire, Hedonia, Novia, Madre, Tango, Sabine, Purgatorio, Centrale). In each the wanderers meet symbolic images, characters, and each of them is somehow connected to religiosity. The three (later four, because a prostitute, Santa, joins them) wanderers also have an aim: they want to free themselves and the world from The Mission, an organisation which controls them and has captured Nima's lover (Gerard). Still, they are missionaries themselves, and only a miracle can save them.

\section{Text in context}

Usually, this novel is characterised as a 'sharp, social-critical thriller which gives retrospective and multicultural perspective on women's place and role in life in in the world' ('Jaunā Gaita', 47). Latvian literary critic Kristiāna Kārkliņa points out the religious parallels in this novel, such as the stations which, to her mind, is an analogue to the 14 stations in Catholic tradition; she also says that the main characters symbolise Joseph and Mary (Kārklina 2013:n.p.) Another reviewer holds a different opinion - that the novel is only about love and has nothing to do with religion, except in symbolism (Viese-Vigula 2013:n.p.). In any case, though, the novel is unusual in the context of Latvian literature, in which realism, historicism and sketching are still the main directions of prose.

Within the context of Latvian literature, the novel should be characterised as innovative and brave. Firstly, Latvian literature rarely focuses on religious issues, and if it does, usually religiosity is characterised in a conventional way, for example a priest's spiritual life and biography (Ābele 2014). Of course, this may be partly explained from the impact of the atheist ideology under Latvia's Soviet occupation religion is a private matter, not societal or, even more, a matter for literary reflection. There are only a few authors who reflect on religiosity as a part of human life and, more unconventionally, for instance, tell the story of an alcoholic Christian (Rokpelnis 2008) or reflect on the 'death of God' (Kolmanis 2005) or religious crisis in the context of gay sexuality (Jansone $2010^{8}$ ). Secondly, also female sexuality is a rarity - the first scandalous book devoted to female sexuality was Romāniņš (A Novel, also An Affair; Rukšāne 2002). Currently, authors such as Inga Gaile, Andra Manfelde, Nora Ikstena and Inga Ābele try to write especially about women, but they are more at home within the second wave of feminism. This means that sex is rarely a topic in such literature; rather, the role of women is given prominence.

8.An analysis of this novel from the viewpoint of queer studies points out that this novel conveys a religiosity that is chosen, thus not as a cultural norm. This is also a fact that should be taken in account: as it was with, for instance, homosexuality in foviet times, also religion was not an issue in Latvian prose, and that tradition has in Soviet times, also religion was not an issue in Latvian
general been continued (cf. Verdins \& Ozolins 2014).
From time to time, issues surrounding sexuality show up in various novels, but only rarely is it one of the main themes.

Inga Žolude (born in 1984) studied English literature at the University of Latvia and at the Southern Illinois University in the USA. She has a PhD in philology and is recognised as one of the most prominent Latvian authors. Santa Biblia is her third novel; for her collection of short stories Mierinājums Ádama kokam (A Solace for Adam's Tree, 2010) she won the EU Prize for Literature. Her works have been translated into English, German, French, Swedish, Polish and other languages.

As a writer, Žolude is a surrealist and naturalist - an unusual combination, and a rarity in Latvian literature. When speaking about Santa Biblia in public, Žolude said that she wanted to write a 'Women's Bible', a feminist novel, which reflects the relationship between women and religiosity (and, of course, reflects also many other things). As a feminist, she is concerned that God in various world religions has turned out to be patriarchal and cruel, especially towards women and everything that has to do with sex and sexuality. There are many naturalistic and quite extreme details in the novel (also a rarity in Latvian literature), which may make reading this novel difficult for some people; still, these details provide a meta-level for the novel. Thus, it can be interpreted as a novel about absence and salvation - as is further shown below.

\section{God, sex and joy}

In Santa Biblia, everybody seems to live in Wonderland everything is turned around. Religion seems to be everywhere, but God is not present in the moment: missionaries walk through the stations, which are full of various expressions of 'sin', and quite often the sin is the result of various religious practices. Most of these practices are offensive to women: circumcision (Žolude 2013:20-21), monastic life supervised by a priest (Žolude 2013:29-40), witch burning (Žolude 2013:50-51), et cetera. Thus, religion is shown as a patriarchal area, where men treat women badly in the name of God, in various ways.

On the other hand, the aim of the missionaries is to save the world, themselves and Nima's lover. As Lev says: 'The world has sinned ... but there is still hope. Hope of something pure and chaste' (Žolude 2013:35). The hope is a Saviour, a child who could be born as a fruit of pure love and chastity.

At Vierge Noire station, they meet also female pastors. It must be added at this point that the question of ordination of women in Latvian churches has become complex since 1993, when a conservative pastor became archbishop of the Latvian Evangelical Lutheran Church (LELC), and he halted the ordination of women. The discussions ended with Synod voting for changing the statutes of the LELC: from 03 June 2016, only men could apply for ordination in the LELC (cf. Pongratz-Lippit 2016). This is why the Vierge Noire station ought to be read also as a protest against church politics. 
Here, at Vierge Noire station, Nima drinks from the basin of water. As it turns out, also one of the missionaries, Lev, is a pastor and man of God. In that station, God seems to be present, because there is a mystery in the air, and everything seems bright and pure. After drinking the water, in one of the next stations (Madre), Nima finds that she is pregnant with a Saviour. As the author shows in this manner, even in a world where a 'patriarchal God' has corrupted humankind, there is still a chance for a woman to save it. Special attention should be paid to Lev as 'man of God' and to women pastors - they are somehow outside institutionalised religion and are thus not connected with church politics. It can be said that Lev and the women pastors are symbols of pure religiosity.

In all other stations, the absence of God is symbolised by the presence of anger and sex. In fact, in Circumcision station, sex is the opposite of sex: there are older women who circumcise young girls, in this way taking away their possibility of sexual enjoyment for life (Žolude 2013:20-21). They will never be able to get joy from a sexual relationship - these women are damned, and this is a result of religious praxis (still, no sign of God in this station).

In Virgin station, they meet many beautiful young girls who all claim to be virgins; as it later turns out, they are not. Besides, the priest turns out to be a monster who exploits girls' sexually; no joy, no God for women here either, and, again, sex is only a means to silence women and to make them obedient. In Hedonia, they meet prostitutes, and Toor falls in love with one named Santa (Žolude 2013:71-80). He marries her in the next station ${ }^{9}$, Novia, and their joy seems from then on to protect missionaries from all evil. An interesting matter: the prostitutes are all about bringing joy (to men, of course), but they are all sad and desperate. Also, Lev says that he does not require carnal joy (Žolude 2013:73). Although Toor and Santa come to dangerous situations, they manage to save themselves, and such joy represents the coming of the Saviour who is born at the end of the novel.

The image of the prostitute within religious context had been used also by the French writer Georges Bataille (1897-1962). In his novel Madame Edwarda, the prostitute is shown as a 'gate', because she has the potentiality of an orgasm. Orgasm, on the other hand, is a means to become aware of one's own death and through that, of the 'death of God', that is, the impossibility of God (Jansone 2013:191-192). Also for Žolude the prostitute is a mediator: she is the only one who can open the book, called - note bene - Santa Biblia (Žolude 2013:167), and she (together with Gerald, in a surreal scene which seems to be a dream of Nima) is with Nima while the Saviour is born.

One important thing in the novel is that all three topoi - God, sex and joy - also occur throughout the novel in their opposites, or in their 'evil forms'. Thus, the novel tells of returning to the possibilities of humankind as an opposite to the possibilities of God. God is not good, loving and caring in 9. Herein too lie some parallels to the Hebrew Bible book of Hosea.
Santa Biblia; rather, God is indifferent to humankind (or 'impossible' or 'absent') and allows humans to do whatever they want, whether it is in his name or not.

Therefore, sex in the novel has an evil form too: it is an instrument for oppressing a woman (hence the Saviour is conceived without a sexual act, although sex is to be found in all the stations). Sex is not in the least human: the author describes prostitutes as unhappy robots who can only be an enjoyment for men..$^{10}$ Sex is associated with blood; it is violent; Nima is even forced to dress as a man in order for her not to be raped. Also, the women are punished for their desire to connect sex with love (as it is the case with the burning witches).

Still, joy is present in the novel, although it seems unbelievable from the narrative alone. The joy is hidden - in Nima's endless love towards Gerard and the necessity that she save him, for his sake, and also the world and humankind. Joy is hidden in hope, represented by Lev, and in the love story of Toor and Santa. Precisely because it is hidden inside humans, joy is the key element of this depressing novel: it shows the possibility of a human, the potential of which is hidden deep inside humanity.

Simultaneously, joy also contains an important theological message. Namely, even in a situation where God seems to have abandoned creation and when various crimes happen in the name of God (such as protest against institutional or patriarchal religion), when humans cannot reproduce themselves any longer (because the world is so scary and dark), then still only a human - a woman - can save the world. Either she is the only one who can read the sacred book (Santa Biblia), or she is the one who gives birth to the Saviour (Nima).

\section{Houellebecq's Soumission ${ }^{11}$}

In a manner which no planning can ever facilitate, this novel about France in the year 2022 coming by democratic means under Islamic control - albeit a very tolerant and in some respects quite French Islamic government - was launched on 07 January 2015: the day of the (in)famous Charlie Hebdo bombings in Paris. Such startling coincidences of history render the 'truth is stranger than fiction' proverb a more morbid than usual validity.

\section{Text in context}

The French term soumission has, among other nuances, the dual public-private connotations of personal servilité ('servanthood', here as a personal orientation) and political vassalité ('vassalhood', as a form of political subjugation, at arm's length). This is very much the theme of Soumission

10.Again, one could say that this is the same as in Bataille's mentioned novel, but it is worth keeping in mind that most feminist interpretations do not take into account Bataille's 'system' (or 'non-system'), that is: the woman is usually a way towards Bataill's 'system' (or 'non-system'), that is: the woman
awareness of God's impossibility (see Jansone 2012:111).

11.Not to be confused with the similarly titled homoerotic bondage-and-discipline novel, Sou-Mission by Marlowe (2015). 
(2015a and 2015b, as is the case with some of Houellebecq's other popular literary offerings). In a futuristic (not in the science fiction sense, most popularly characterised by advanced technology and interstellar events) France, a moderate Islamic party comes to rule via elections and coalition, and this changes many aspects of life: religion becomes a more normal, less publicly side-lined aspect of French life; sex becomes at once more regulated (less free, with the role and clothing of women in public society more strictly regulated; cf., e.g., Houellebecq 2015a:1. 1557-1562) ${ }^{12}$ and more abundant (polygamy becomes standard practice, also - and on purely evolutionary grounds: Houellebecq 2015a:1. 578; cf. Houellebecq 2015a:1. 704 - for intellectuals; cf., e.g., Houellebecq 2015a:1. 1603-1606, where relationships between male professors and young female students are more or less encouraged). In this, the main character, a Sorbonne professor of literature (e.g. Houellebecq 2015a:1. 177) called François, after initially trying to flee these developments in the French countryside finds unexpected happiness and contentment. This is given expression to in a Sermon on the Mount-like saying (Houellebecq 2015a:1. 182): 'Happy are those who are satisfied by life, who amuse themselves, who are content ${ }^{\prime}$ - a genre of wisdom that is found frequently in this novel (and, if the sense expressed in Lombaard 2015c:82-95 is correct, should in the coming decades become a more widely accepted form of existentialreligious pronouncement).

To some extent, the novel can be classified as it has been in some reviews - 'dystopia', yet we do not fully agree with such assessments. The reason is simple - it is about the near future (just a few years) and, when compared to such 'dystopian classics' as George Orwell's '1984' or Margaret Atwood's 'MadAdam', or even the Haruki Murakami trilogy '1Q84', it lacks such a scope in the plot as well as apocalyptic characteristics. Dystopia is found only in the passages right after the election, where François drives away from the city in his car. The apocalypse is not even close, the world is not about to end - it is about to change, yes, but politically and in the way people think. In other words, the novel is too realistic to be a form of dystopia; rather it is a political interpretation of what is about to happen. As Preston (2015) puts it:

Rather than being a dark vision of a world ruled by mad mullahs, it presents the moderate Muslims who take over France as a force of spiritual integrity and revolutionary verve, 'a historic opportunity for the moral and familial rearmament of Europe', the real targets of the book are France's bloated institutions, its venal politicians, its sclerotic literary scene. (n.p.)

The book's reception in various countries also was ambiguous. ${ }^{13}$ Karl Ove Knausgaard puts it precisely:

As is now well known, 'Submission' was first published on the same day as the attack on the French satirical magazine Charlie Hebdo, in which 12 innocent people were killed. Houellebecq

12.The references given here are to the Kindle edition of Submission, with the Kindle assigned location number given, e.g. 'I. 23 ' = location 23.

13.In Latvia, alongside with the publication of translation, the play was also produced in Riga New Theatre (director Alvis Hermanis), thus giving rise to the discussion between left-wing politicians and publicists. Hermanis was even called 'a xenophobe'. himself was featured on the magazine's front page that week, and since he had once said in an interview that Islam was the stupidest of religions, and since Islam supposedly played such a prominent role in his latest book, his name immediately became associated with the massacre. The French prime minister announced that France was not Michel Houellebecq, was not a country of intolerance and hatred. Houellebecq was held up as a symbol of everything France was not, a symbol, indeed, of everything undesirable, and this in a situation in which human beings had been killed - one of Houellebecq's own friends among them, we later learned - so that it soon became impossible not to think of him and the killings together. He was, by virtue of having written a novel, connected with the murders, and this was affirmed by the highest level of authority. (Knausgaard 2015:n.p.)

It must be added that for his statement that Islam is the stupidest religion (which he made while promoting his novel Platform), Michael Houllbecq was sued. Also, he has been accused in misogyny and racism because of his literary works.

Interestingly, François - as is the case with Pippa in Die donker god - also has a main literary source that influences in various ways, and times varyingly, his life, political views, work, and attitudes on matters such as religion, relationships and a meaningful existence. In this case, it is not a story as it is for Phillips, nor a sacred book as it is for Žolude, but a writer, J.K. Huysmans, and his entire oeuvre, which François knows very well, having written his doctoral dissertation about him (1. 32), and with much of his subsequent scholarly writing devoted to him too. In many ways, the Huysmans intertextualities colour the character of François (e.g. Houellebecq 2015a:1. 82, 164, 377, 821, 1507) and this novel by Houellebecq.

Also, concerning the other theme of this contribution - in one of his interviews, Houellebecq has said: 'I'd say that the question whether love still exists plays the same role in my novels as the question of God's existence in Dostoyevsky' (Hunnevell 2010:n.p.). When asked to explain his assertion, Houellebecq stated that love loses its power nowadays, and that the materialist thought - that we are born alone, live alone and die alone - is causing the disappearance of love.

\section{God, sex and joy}

Acts of religion, despite the main character François's seemingly a-religious attitude in general, are often mentioned, and as the novel progresses, more appreciatively. From the opening quotation from Huysmans (Houellebecq 2015a:1. 23 and 25), throughout the novel in many ways (e.g. Houellebecq 2015a:1. 1915), and including François's conversion recital in the Paris mosque (Houellebecq 2015a:1. xx), aspects of faith are highlighted.

The appreciation François regains for religious matters (e.g. Houellebecq 2015a:1. 2247) is not isolated from other aspects of life: he sees many things in decline, such as literature 
(Houellebecq 2015a:1. 48-52), architecture (Houellebecq 2015a:1. 2252), art (Houellebecq 2015a:1. 1921), sexual acts (Houellebecq 2015a:1. 2264), love and family life (Houellebecq 2015a:1. 109, 117, 293, 579). Also, as he confesses to himself:

And yet in the morning after I defended my dissertation (or maybe that same night), my first feeling was that I have lost something priceless, something I'd never get back: my freedom. (Houellebecq 2015a:1. 68)

Throughout the novel François keeps searching for freedom, trying different ways and, ironically, he finds that freedom by means of normative religion: at last he is able to feel happy again.

In a kind of return to the pre-modern period in Europe, when Islam was the cultural grouping that kept much of ancient and essential Western philosophy alive, François sees that occurring in the France of his time (and per implication, our time) too (e.g. Houellebecq 2015a:1. 1576). The joy of literature is however a kind of nihilistic affair (Houellebecq 2015a:1. $80-82)$, as is the combination of sex, religion and food (Houellebecq 2015a):

The man, destroyed at the moment of his assumption, would utter a few weak words: appallingly weak in the French films ('Oh putain!' 'Oh putain je jouis ${ }^{14} ! ':$ more or less what you'd expect from a nation of regicides), more beautiful and intense from those true believers the Americans ('Oh my God!' 'Oh Jesus Christ!'), like an injunction not to neglect God's gifts (blow jobs, roast chicken). At any rate I got a hard-on, too, sitting in front of my twenty-seven-inch iMac, and all was well. (1. 172)

Such cynicism and disillusionment with French culture leads François to depression (e.g. Houellebecq 2015a:1. 336, 850, 856, 1809, 1819-1823), including a loss of sexual appetite and thoughts of suicide. Still, there is an internal debate with not god, but religion, literature and joi de vivre (Houellebecq 2015a $)^{15}$ :

... the prose of Dom Jean-Pierre Longeat-no doubt an excellent monk, full of love and good intentions-exasperated me more and more. 'Life should be a continual loving exchange, in tribulations or in joy', the good father wrote. 'So make the most of these few days and exercise your capacity to love and be loved, in word and deed'.

'Give it a rest, dipshit', I'd snarl, 'I'm alone in my room'.

'You are here to lay down your burdens and take a journey within yourself, to the wellspring where the power of desire is revealed'.

'My only fucking desire is to have a fucking cigarette', I raged ... (1. 1929)

14.The dual meanings of this word in French, to experience joy and to have an orgasm should not escape one here.

15.See also Houellebecq 2015a:I. 2193: 'You aren't Catholic, are you? That could be a problem. No, in fact; I couldn't say that I was. "And I don't guess you're really an atheist, either. True atheists are rare". "You think? On the contrary, I'd have said that atheist, either. True atheists are rare . "You think? On the contrary, I'd have said that most people in the Western world are atheists". "Only on the surface, it seems to me. The only true atheists I've ever met were people in revolt. It wasn't enough for them to coldly deny the existence of God-they had to refuse it, like Bakunin: 'Even if God existed, it would be necessary to abolish him. They were atheists like Kirilov in The ossessed. They rejected God because they wanted to put man in his place. The were humanists, with lofty ideas about human liberty, human dignity. I don't suppose you recognize yourself in this description". No, in fact, I didn't; even the word humanism made me want to vomit ...'
Interestingly, as François approaches his conversion ${ }^{16}$ - his 'spiritual journey' (Houellebecq 2015a:1. 1938), his 'journey in the light' (Houellebecq 2015a:1. 1941) - his sexual experiences with either clearly stated or implied Muslim women become more satisfying for him (e.g. Houellebecq 2015a:1. 1633, 16551740), whereas earlier he had found it with his deepest love, the Jewish Myriam (Houellebecq 2015a:1. 296, 383, 856), whom he loses through her emigration to Israel. However, 'peace through interfaith dialogue' (Houellebecq 2015a:1. 1331; cf. Houellebecq 2015a:1. 1365, 1370, 1765) remains a viable model. This may well be symbolically read, as Islam in this 2020s world replacing not only France's Catholic heritage but also the Jewish influences in its culture, but not in a harsh way; more by cultural means. A short monastic stay by Francois parallels, unsuccessfully, his icon Huysmans's monastic stay (Houellebecq 2015a:1. 860-862). More meaningfully, François finds solace in regular visits to an ancient pilgrimage site, the Black Madonna at Rocamadour (cf. Houellebecq 2015a:1. 1414, 1465, 1479, 1499, 1513). He in time seeks for a deepening of French culture and traditions, in a very un-laïcité way, in the general faith traditions of - as formulated in Houellebecq 2015a:1. 1334 - 'the three religions of the Book' (Houellebecq 2015a):

... everyone had to admit that times had changed. More and more families—whether Jewish, Christian, or Muslim—wanted their children's education to go beyond the mere transmission of knowledge, to include spiritual instruction in their own traditions. This return to religion was deep, it crossed sectarian lines, and public education could no longer afford to ignore it. It was time to broaden the idea of republican schooling, to bring it into harmony with the great spiritual traditionsMuslim, Christian, or Jewish—of our country. (1. 948)

Happiness is for him in the end found in the combination of God and sex... (Houellebecq 2015a):

The shocking and simple idea, which had never been so forcefully expressed, that the summit of human happiness resides in the most absolute submission. I hesitate to discuss the idea with my fellow Muslims, who might consider it sacrilegious, but for me there's a connection between woman's submission to man, as it's described in Story of $\mathrm{O}^{17}$ and the Islamic idea of man's submission to God ... (1. 2305)

On the other hand, François thinks about Christianity with words that hint at this religion being something of the past: 'The old queer Nietzsche was right: Christianity, was, at the end of the day, a feminine religion' (Houellebecq 2015a:1. 1924). There are at least two important things in this sentiment. Firstly, Christianity is gone. Does it mean that a human being requires a new religion? Secondly, Christianity is pictured as a feminine religion; the reader is tempted to think that humans may require a new religion which is not feminine. Islam, as an answer, is quite a masculine religion humanity is subordinated to God, while women are subordinated to men.

16.This involves merely the acknowledgment of an order in the universe, and the status of Mohammed as prophet - cf., e.g. Houellebecq 2015a:I. 2215-2222, 2233, 2295, 2326

17. Histoire d'O is a pseudonymously published mid-20th century erotic novel (Réage 1954), which has become a standard reference in discussions on modern erotic works of fiction, especially in relation to dominance-submission thematics. 


\section{Discussion}

\section{$3 \times 3$-letter words novelised, compared and contrasted}

Drawing on the above, a few general concluding remarks may be made - not in the mode of statements that characterise widely the interrelationship between God, sex and joy in literature; such statements would require a preparatory encyclopaedic study. On a more modest scale, though, it remains interesting to note here that in none of the three novels under discussion is the God-sex-joy relationship presented as something problematic. This may not be entirely surprising, because literature along with all other forms of good art has always found itself presenting alternatives to matters broadly perceived in a certain manner in wider society. Art, in this sense (thus excluding most 'commercial art', though not all, as e.g. the oeuvre of Andy Warhol has demonstrated) is often a fringe activity in society; it carries an inherent avant-garde tendency, showing unthought-of or unpopular alternatives, only some of which in time society follows more readily. The fact that religion could so freely function within such a public medium as a novel is in these three cases moreover an indication of what has been characterised above as postsecular cultural trends. ${ }^{18}$ Of the three novels discussed here, that by Houellebecq is in this particular respect the most noteworthy, given the reticence on matters religious in French public life and the manner in which Islam now has such a strongly constitutive role to play in Soumission.

Furthermore, in these three cases, the positively viewed God-sex-joy relationship is explored, noticeably, with both the divine and the sexual not described in mainstay ways. The religious thematics are out of the ordinary, with the God-talk unusual; the sexualities described may be characterised as alternative; this is 'strange love' (Bennett 2011, translated). There is some coherence to this, that the divine and the sexual are treated in unusual ways, because such treatment fits well with these two topoi being brought into relation with one another, and positively so, namely as aspects of a joyful life.

Though the thematics overlap, such a coincidence lies in the fact that God, sex and joy are related to one another, and not in any parallel treatment of the three topoi. The differences are clear to see. When it comes to the divine, for instance, in Die donker god the god is a man who appears unexpectedly, is worshipped in a manner known from romance novels and becomes a devil in the manner of horror novels. In Santa Biblia, religion is omnipresent, but God is absent - an unusual oppositioning. In Soumission, an initial religious vacuum in society and in the awareness of the main character is filled by a form of Islam which, though not hard line, is by no means liberal as that would be understood in Christian or formerlyChristian democracies. The saviour-like figures who provide a kind of denouement as these respective thematic lines

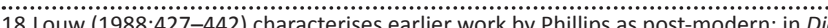
donker god, a closer description would be post-secular. It is not unusual to find the work of Phillips employing rarely used genre techniques in Afrikaans literature (Van Wiekerk 2010:368; cf. Holden 2013:12; Muller 1991:42, 45; more broadly Renders Niekerk 2010:368; cf. Holden 2013
2009:70-82; Steenkamp 1993). unfold are fully dissimilar. The same holds for the aspects of the world 'outside' the novels to which they as artworks in some respects relate: with Die donker god, domestic abuse in which patriarchy plays such a demonic role in South Africa; with Santa Biblia, the ordination of women as clergy in Latvia; with Soumission, the long-standing political matter of the exclusion of religion from French public life (laïcité). Relating to the sexual, the move in Die donker god is from the romantic, almost holy to the hellishly abusive; in Santa Biblia sex seems ubiquitous but is generally abusive and inhumane, with pregnancy and hence hope then resulting from something purer: water; in Soumission, sex moves from the non-religious to the religious sphere and from the (serially) monogamous to authorised polygyny. In all three novels, joy plays variously into these two topoi, in a manner in which no pattern can be discerned that would be valid across the three novels.

The fact that this all occurs in three such different cultural contexts in novels in which there can be no expectation of direct influence, is not without meaning: in a variedly cultural way, a surprising confluence presents itself of Godsex-joy, in interplay, occurring unexpectedly across the divides between these texts. The sample of texts here is much too small to attempt any broad conclusions on unfolding religiosities or sexualities, and the manner in which the three texts have been arrived at are more personally constituted than determined by, for instance, strictly representational criteria from the international literary scene, as described earlier. However, it is precisely because of the unexpected nature of these thematic overlaps in literature from such disparate backgrounds that this contribution has come into being. Something previously unanticipated has been identified by the authors, and it is noteworthy enough simply to put forward this observation. If this God-sex-joy interplay seems to be a rare occurrence, then at the very least something uncommon or perhaps exceptional has by chance been noted, which in itself is a valid intellectual contribution. If it later seems that a parallel overlap of topoi presents itself in other literary endeavours, the heuristic value of the present contribution would be increased. In any case, however, the thematic engagement of the topoi of God, sex and joy seems a valuable interpretative perspective on the three novels discussed above, giving greater insight into one part of the literary textures presented by them, as something apart from the usual interpretative avenues such as narration, plot, characterisation, symbolism and so forth.

\section{Acknowledgements Competing interests}

The authors declare that they have no financial or personal relationships that may have inappropriately influenced them in writing this article.

\section{Authors' contributions}

The two authors of this article each contributed equally to the completed article. 


\section{References}

Ābele, I., 2014, Klūgu mūks, Dienas Grāmata, Rīga.

Annelise, 2007, Maanvrug, Godin-Onbeperk, Pretoria.

Aucamp, H., 2011, Lendetaal. Homoërotiek in die kunste en in die letterkunde, Protea Boekhuis, Pretoria.

Bailey, E., 1997, Implicit religion in contemporary society, Kok Pharos, Kampen

Bennett, N., 2011, 'LitNet Akademies resensie-essay: Net 'n lewe as 'n feministiese teks', viewed 26 March 2016, from http://www.litnet.co.za/net-n-lewe-as-nfeministiese-teks

Benson, I.T., 2012, Living together with disagreement: Pluralism, the secular and the fair treatment of beliefs in law today, Connor Court Publishing, Ballan, Australia.

Boyce-Tillman, J., 2015, Experiencing music. Restoring the spiritual, Springer, London.

Csíkszentmihályi, M., 1990, Flow. The psychology of optimal experience, HarperCollins, New York.

Cupitt, D., 1988, Mysticism after modernity, Blackwell, Oxford

De Beauvoir, S., 1949, Le Deuxième Sexe, Gallimard, Paris.

Eaves, M. (ed.), 2003, The Cambridge companion to William Blake, Cambridge University Press, Cambridge.

Flanagan, K. \& Jupp, P.C. (eds.), 2007, The sociology of spirituality, Ashgate, Aldershot.

Foucault, M., 1977, 'A Preface to transgression,' in D.F. Bouchard \& S. Simon (eds.), Language, counter-memory, practice, pp. 29-52, Cornell University Press, Ithaca.

Goosen, D., 2007, Die nihilisme. Notas oor ons tyd, Praag, Pretoria.

Habermas, J., 2008, 'Secularism's crisis of faith: Notes on post-secular society', New Perspectives Quarterly 25, 17-29. https://doi.org/10.1111/j.1540-5842.2008.01017.x

Hart, T. \& Khovacs, I. (eds.), 2007, Tree of tales. Tolkien, literature and theology, Baylor University Press, Waco.

Hamilton, W., 1989, Reading Moby dick and other essays, P. Lang, New York.

Hay, D. \& Nye, R., 2006, The spirit of the child, Jessica Kingsley, London.

Hochheimer, J.L. \& Schmidt, W.S. (eds.), 2013, Spirituality in the 21st century: Explorations, Inter-Disciplinary Press, Oxford.

Holden, Y., 2013, 'Die neerslag van enkele sprokies in geselekteerde Afrikaanse literêre tekste, met spesifieke verwysing na die teks Eenduisend-en-een grimmige nagte - Die toring met twaalf vensters', Unpublished MA dissertation, University of Pretoria, Pretoria.

Houellebecq, M., 2015a, Submission, transl. L Stein, Farrar, Straus and Giroux, New York. Houellebecq, M., 2015b, Soumission, Flammarion, Paris.

Hunnevell, S., 2010, 'Michel Houllebecq. The Art of Fiction No. 206', The Paris Review, Issue 194, Fall 2010, viewed 25 January 2017, from https://www.theparisreview. org/interviews $/ 6040 /$ michel-houellebecq-the-art-of-fiction-no-206-michelhouellebecq

Jansone, I., 2010, Insomnia, Dienas Grāmata, Rīga.

Jansone, I., 2012, Thinking about God after the "Death of God": An Interpretation of George Bataille's Novels, Doctoral thesis, University of Latvia, Riga.

Jansone, I., 2013, 'Image of the prostitute as the representation of the divine: Divinus Deus of Georges Bataille (summary)', in D. Hanovs, I. Jansone \& K. Vērdinš (eds.) Dzimtes konstruēšana I, pp. 190-191, Institute of Literature, Folklore and Art/ Avens un partneri, Rīga.

Kārkliṇa, K., 2013, 'Gadsimta Jēzus. Inga Žolude Santa Biblia', Portal for literature and literary critics Ubisunt, viewed 24 January 2017, from http://www.ubisunt.lu.Iv/ zinas/t/23939/

Kearney, R., 2010, Anatheism: Returning to God after God, Columbia University Press, New York.

Kleinboer, 2003, Kontrei, Praag, Pretoria.

Knausgaard, K.O., 2015, 'Michel Houellebecq's "Submission"', New York Times, 02 November, viewed 25 January 2017, from https://www.nytimes.com/2015/11/08/ books/review/michel-houellebecqs-submission.html?_r=1

Kolmanis, A., 2005, Žūpa Amors jeb mirušais Dievs, Atēna, Rīga.

Kourie, C., 2009, 'Spirituality and the university', Verbum et Ecclesia 30(1), 148-173. https://doi.org/10.4102/ve.v30i1.67

Lewis, C.S., 1955, Surprised by joy: The shape of my early life, G. Bles, London.

Lohfink, N., 2003, Qoholet: A continental commentary, Fortress Press, Minneapolis, MN.

Lombaard, C., 2009a, 'Translating human rights between the secular and the spiritual - Two recent attempts', in E.F. Coutinho (ed.), Discontinuities and displacements. Studies in comparative literature (Proceedings of the XVIIIth congress of the International Comparative Literature Association), pp. 334-347, Aeroplano Editora, Rio de Janeiro.

Lombaard, C., 2009b, 'Orgasms and hallelujahs, or, Christian Spirituality and sexuality - A missionary position', Missionalia 37(1), 103-123.
Lombaard, C., 2009c, 'Two approaches to life in the second temple period: Deuteronomy and Qoheleth', HTS Theological Studies/Teologiese Studies 65(1), 1-4. https://doi.org/10.4102/hts.v65i1.185

Lombaard, C., 2014, 'Getting texts to talk. A critical analysis of attempts at eliciting contemporary messages from ancient holy books as exercises in religious communication', Nederduitse Gereformeerde Teologiese Tydskrif 55(1), 205-225. https://doi.org/10.5952/55-1-2-522

Lombaard, C., 2015a, 'Godness, goodness and scriptures: The interlinked societal experience of faith, morality and the Bible', Presentation at LCC International University, Klaipeda, Lithuania, 17 April.

Lombaard, C., 2015b, Spirituality - A way of life, I: The Times of God and Acts of Faith (Coursework book), Theological Education by Extension College, Southern Africa, Johannesburg.

Lombaard, C., 2015c, "'And never the twain shall meet"? Post-secularism as newly unfolding religio-cultural phase and Wisdom as ancient Israelite phenomenon. Spiritualities and implications compared and contrasted', Journal of Theology for Southern Africa 152, 82-95.

Louw, S., 1988, 'Transformasie/transmutasie in Fransi Phillips se sewe \& sewentig stories oor 'n clown', Journal of Literary Studies/Tydskrif vir Literatuurwetenskap 4(4), 427-442. https://doi.org/10.1080/02564718808529887

Marlowe, S., 2015, Sou-mission, transl. A.C. Clarke, Me and the Muse Publishing, Senheim.

Maeterlinck, M., 1892, Pelléas et Mélisande, Paul Lacomblez, Bruxelles.

Muller, M., 1991, 'Grondliggende algoritme vir postmodernisme', Journal of Literary Studies/Tydskrif vir Literatuurwetenskap 7(1), 38-51. https://doi.org/ 10.1080/02564719108529967

(No author), Spring, 2014, Dažos vārdos. Periodical "Jaunā Gaita”, No.276:47

Nynäs, P., Lassander, M. \& Utriainen, T. (eds.), 2012, Post-secular society, Transaction Publishers, New Brunswick.

O'Sullivan, M. \& Flanagan, B. (eds.), 2012, Spiritual capital: Spirituality in practice in Christian perspective, Ashgate, Farnham.

Pinkerton, S.D., Cecil, H., Bogart, L.M. \& Abramson, P.R., 2003, 'The pleasures of sex: An empirical investigation', in J.A. Russel (ed.), Pleasure, pp. 341-353, Psychology Press, Hove.

Phillips, F., 2007, Die donker god, Umuzi, Roggebaai.

Pongratz-Lipitt, C., 2016, 'Latvian Lutheran Church rules that women cannot be ordained priests', viewed 21 June 2016, from http://ncronline.org/blogs/ncrtoday/latvian-lutheran-church-rules-women-cannot-be-ordained-priests

Preston, A., 2015, 'Submission by Michael Houellebecq review - Satire that's more subtle than it seems', The Guardian, 08 September, viewed 25 January 2015, from
https://www.theguardian.com/books/2015/sep/08/submission-michelhttps://www.theguardian.com/books/2
houellebecq-review-satire-islamic-france

Réage, P., 1954, Histoire d'O, Jean-Jacques Pauvert, Paris.

Renders, L., 2009, 'Sprokies is nie waar nie: Die donker god van Fransi Phillips', Stilet: Tydskrif van die Afrikaanse Letterkundevereniging 21(1), 70-82.

Rokpelnis, J., 2008, Virtuālais Fausts, Dienas Grāmata, Rīga.

Rukšāne, D., 2002, Romāniňš, Atēna, Rīga.

Russel, J.A. (ed.), 2003, Pleasure, Psychology Press, Hove.

Russell, B., 1930, The conquest of happiness, George Allen \& Unwin Ltd, London.

Scheffler, E.H., 1996, Prediker se positiewe raad (professorial inaugural address), University of South Africa, Pretoria.

Schneiders, S., 2003, 'Religion vs. Spirituality: A contemporary conundrum', Spiritus: A Journal of Christian Spirituality 3(2), 163-185. https://doi.org/10.1353/ scs.2003.0040

Sen, A., 1985, 'Well-being, agency and freedom', The Journal of Philosophy LXXXII(4), 169-221.

Steenkamp, A., 1993, 'Die postmoderne, die sprokie en die mitiese in die werk van Fransi Phillips', Unpublished MA dissertation, University of Pretoria, Pretoria.

Taylor, C., 2007, A secular age, Harvard University Press, Cambridge, MA.

Vanhoutte, K., 2015, 'And the word turned once more to the flesh. Or on the various "theological turns" in contemporary continental philosophy', presentation at "The Interplay between Theology and other Disciplines in Research and in Theological Education" Conference, April 14-16, Faculty of Theology, University of Latvia, Riga.

Van Niekerk, A., 2010, 'A woman who made her mark in history but remained marginalised in the documents of history: Petronella van Heerden', Journal of Literary Studies/Tydskrif vir Literatuurwetenskap 14(3-4), 348-374.

Verdins, K. \& Ozolins, J., 2014, 'Is Ilze Jansone's Insomnia the Latvian Well of Loneliness?', Interlitteraria 19(1), 202-210. https://doi.org/10.12697/ IL.2014.19.1.15

Viese-Vigula, I., 2013, 'Svētās spogulspēles', Satori (Recenzija) 1/4, viewed 09 June 2017, from http://www.satori.Iv/article/svetas-spogulspeles

Žolude, I., 2013, Santa Biblia, Dienas Grāmata, Rīga. 